Mitteilungen der Österreichischen Geographischen Gesellschaft, 160. Jg., S. 331-350

(Annals of the Austrian Geographical Society, Vol. 160, pp. 331-350)

Wien (Vienna) 2018, https://doi.org/10.1553/moegg160s331

\title{
Female Street Namesakes in Selected Polish Cities
}

\author{
Justyna B. WALKOWIAK, Poznań (Poland)* \\ Initial submission / erste Einreichung: 02/2018; revised submission / revidierte Fassung: 12/2018; \\ final acceptance / endgültige Annahme: 12/2018 \\ with 2 tables in the text
}

\section{Contents}

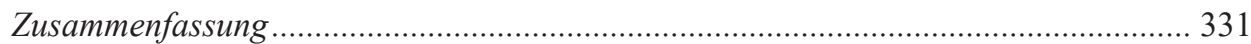

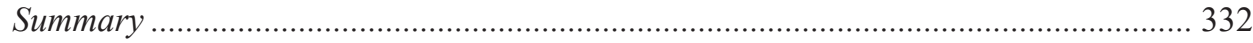

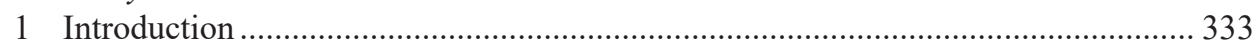

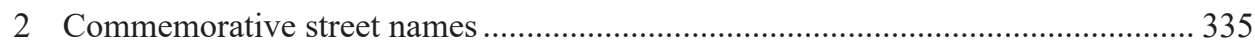

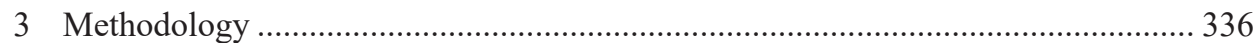

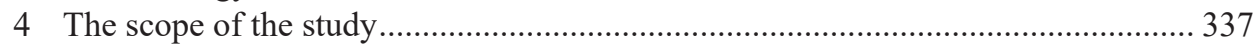

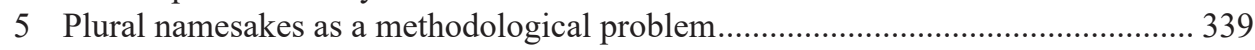

6 Other uncertain issues .................................................................................... 340

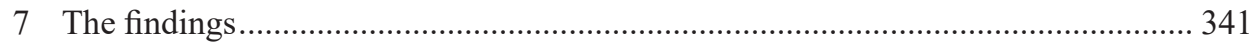

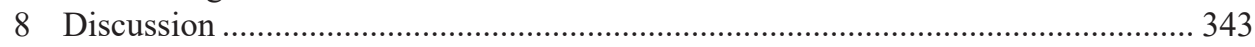

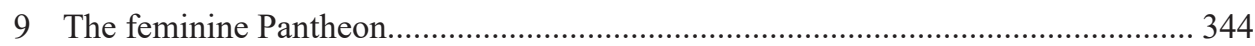

10 Perspectives for the female ratio in commemorative hodonymy ........................... 347

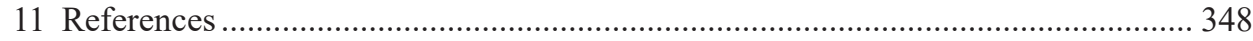

\section{Zusammenfassung}

\section{Weibliche NAmensGeber In DEN StrassenNAMEN AUSGEWÄHLTER POLNISCHER STÄDTE}

Der Artikel bietet eine vorläufige Analyse der Sichtbarkeit von Frauen in den Namen von Straßen in ausgewählten polnischen Städten. Die Idee der Geschlechterparität in der Straßenbenennung ist in Polen neu und dieser Artikel ist wahrscheinlich der erste Versuch in der polnischen wissenschaftlichen Literatur, diese Thematik zu bearbeiten. Die vorliegende Studie umfasste zwölf polnische Städte mit der höchsten Anzahl von Hodonymen: Warschau [Warszawa], Krakau [Kraków], Posen [Poznań], Łódź, Bres-

\footnotetext{
* Dr. Justyna WaLKowiak, Department of Language Policy and Minority Studies, Chair of Oriental Studies, Adam Mickiewicz University Poznań, Wieniawskiego 1, PL-61-712 Poznań, Poland; email: justwalk@amu. edu.pl
} 
lau [Wroclaw], Stettin [Szczecin], Danzig [Gdańsk], Bromberg [Bydgoszcz], Lublin, Kattowitz [Katowice], Tschenstochau [Czesstochowa] und Białystok. Die Auswahl umfasst Städte mit teilweise sehr unterschiedlicher historischer Entwicklung als Folge verschiedener fremder Einflüsse und mit differenziellen Bevölkerungsstrukturen (z. B. Dominanz autochthoner Bevölkerung oder Bevölkerungsaustausch und starke Zuwanderung) und kann deshalb als repräsentativer Querschnitt betrachtet werden. Die Gesamtzahl der analysierten Namen von Straßen, Plätzen und Brücken in diesen Städten betrug 25.500, wobei jene Namen, die nach einzelnen Personen (historischen oder fiktiven) benannt waren, je nach Stadt zwischen einem Viertel und über 40 Prozent aller Namen variierten. In der Studie wurden nur Einzelpersonen als Namensgeber (Straßenpatrone) von Straßen, Plätzen und Brücken analysiert, da es bei Pluralformen oft unklar war, ob sie als männlich oder weiblich zu behandeln sind. Die Untersuchung von insgesamt mehr als 7.700 Straßenpatronen ergab eine starke Dominanz männlicher Personen, die im Durchschnitt 89 Prozent aller auf Einzelpersonen bezogenen Straßennamen ausmachten. Interessanterweise war diese Dominanz nicht nur in Bezug auf historische Personen, sondern auch auf fiktive Gestalten (mythologische oder literarische) sichtbar. Zwischen den einzelnen Städten waren die Unterschiede im Anteil der männlichen Straßenpatrone nicht groß und sie sind kaum direkt auf die historischen Merkmale bestimmter Städte zurückzuführen. Aus den Tendenzen der Namensgebung für Straßen, Plätze und Brücken in den Städten an Frauen ergibt sich ein unerwartetes weibliches Pantheon.

Schlagwörter: Hodonyme, Straßennamen, Geschlechterparität, Straßenbenennung, weibliche Straßennamensgeber (Straßenpatrone)

\section{Summary}

The article purports to offer a preliminary analysis of the visibility of women in the names of streets in selected Polish cities. The very idea of gender parity in urban naming is novel in Poland and the present article is probably one of the first such attempts in Polish scholarly literature. The study comprised twelve Polish cities with the highest number of hodonyms: Warsaw [Warszawa], Cracow [Kraków], Poznań, Łódź, Wrocław, Szczecin, Gdańsk, Bydgoszcz, Lublin, Katowice, Częstochowa and Białystok. With different historical circumstances, diverse foreign influences and population characteritics (e.g. autochthonous vs. immigrant), the selection renders the analysis representative. The total number of analysed names of streets, roads, city squares and bridges in those cities was about 25,500, of which those named for individual people (historical or fictitious) varied from one fourth to over 40 percent from city to city. Only individual namesakes have been analysed, since in the case of plural ones it was often unclear whether to treat them as masculine or feminine. The examination of a total of over 7,700 streets named for individual people revealed a heavy bias towards male characters, who constituted on average 89 percent of individual commemorations. Interestingly, this tendency was visible not only with regard to historical figures, but also to fictitious characters (mythological or literary). The differences between cities in the ratio of male namesakes 
were not huge, and they were hardly traceable directly to the historical characteristics of particular cities. From the tendencies in urban naming an unexpected female pantheon emerges.

Keywords: Hodonyms, gender parity, street naming, female street namesakes

\section{Introduction}

The aim of the present article is to offer a preliminary analysis of the visibility of women in the names of streets in selected Polish cities. To the best knowledge of the author, such an attempt has not been made so far, despite the development of gender studies in Poland over the past several years. A special reason to do so is the centenary of active and passive voting rights for Polish women, which fell in 2018 (similarly e.g. to Austria, Germany, Great Britain or Ireland).

The topic itself was introduced to public discourse in Poland not long ago, when Robert Biedroń, the mayor of Słupsk ${ }^{1)}$, noted that in this town there were 202 street names devoted to men and only 19 to women. He put forward the proposal that there should be a parity in city naming and suggested quotas. According to his project of March 2015, the number of women and men as namesakes of streets in Słupsk was to be the same. This principle was to apply only to newly named streets - and of these, only to those where the naming was to be done by the local government and not to the cases where a group of inhabitants would come up with a naming proposal as a grassroots initiative. Biedron's idea was ridiculed and on 30 September 2015 the councillors of Słupsk rejected in voting even the softened version of the proposal. ${ }^{2}$ According to one of the women [!] councillors, gender parity in street naming is a contradiction of common sense (Protokół ... 2015, p. 59). On this occasion it was brought to the attention of the public that out of the ten new street names bestowed in Gdańsk since 2013, only one commemorated a woman; in the nearby Gdynia there was only one female name out of nine, and in Sopot the two new names were both male.

While a completely novel idea in Poland, the debate and the issue itself are in fact not so new. In August 2015 The Independent wrote:

A feminist group in France has been transforming the streets of Paris after noting that just 2.6 percent are named after notable women. Tourists on the Ile de la Cité got a surprise when they found that almost all of the street signs in central Paris had been changed overnight. The group Osez le Féminisme!, which roughly translates as "dare to be a feminist", created their own version of the iconic blue plaques and stuck them over the "official" names.3)

1) A seaside Polish town with a population of about 93,000 .

2) http://www.tvn24.pl/pomorze,42/slupsk-prezydent-chce-parytetu-w-nazwach-ulic,521300.html (accessed Feb. 16, 2018); https://wiadomosci.wp.pl/nie-dla-parytetow-w-nazwach-ulic-w-slupsku-biedron-to-kleska-demokracji-602766 3186854529a (accessed Feb. 16, 2018).

3) http://www.independent.co.uk/news/world/europe/feminists-in-france-change-paris-street-names-to-celebrate-inspirational-women-10474690.html (accessed Feb. 16, 2018) 
Moreover, a large proportion of the 166 women immortalised in Parisian hodonymy merited the honour by being spouses or daughters of famous men. The changes in Parisian street naming affected 60 roads, but were very short-lived.

Not all initiatives are so radical, yet many are seminal. In the USA, a group Equal Visibility Everywhere strives to achieve gender parity in diverse spheres of everyday life, including coins and postal stamps, monuments and memorials on the local, state, and national level, as well as the names of streets and public buildings, including schools. ${ }^{4)}$ A 2015 study of seven big cities - London, Paris, San Francisco, Mumbai, New Delhi, Chennai and Bangalore - revealed that, on average, only 27.5 percent of streets had female names (Poon 2015). In the spring of 2016 Toponym'Elles, the first feminine toponymic bank, was created in Montreal. Its aim is to increase the visibility of women in the public space by including in it 375 names of women worthy of recognition on the occasion of the city's $375^{\text {th }}$ anniversary. ${ }^{5}$ As the founders of the name bank established, men account for over 50 percent of the hodonymy of contemporary Montreal, with merely 6 percent of streets named for women, even though since 2010 one out of five new place names has memorialised women.

In France, an initiative was undertaken in the autumn of 2017 by two women members of the French Parliament, Sophie Auconie and Annick Billon, that every town in France should name a street after some woman. ${ }^{6}$ In Italy, a few years ago an analysis was initiated of the streets of Rome in terms of gender parity. ${ }^{7}$ It was found that merely 3.5 percent of over 16,500 streets were named for women (BOSWORTH 2012).

In most municipalities of Spain, the percentage of streets named for women does not exceed 10, with the average around 5 percent. Most of the female commemorations in Spain are those of saints or nuns; in Madrid alone, 730 hodonyms are religiously motivated, including 352 male and 125 female saints. The second largest group are queens and the wives of public personages. In an attempt to rectify this situation, as early as 2005 the municipal authorities of Córdoba, where the female ratio was 6 percent (with half of the names invoking Virgin Mary), decided on the 50 percent gender quota for urban naming (Tojo 2015).

It was also in 2005 that the Berlin borough of Friedrichshain-Kreuzberg decided on the same percentage of women in future street naming. Until this quota is met, no new streets may be named for men (KENSCHE 2013). Of the streets of Antwerp named for people, which constitute approximately one third of the total, only 7 percent have female referents. In the future, it is planned, half of the newly baptised streets will be dedicated to women: a list of 60 deserving namesakes has already been compiled. ${ }^{8)}$

\footnotetext{
4) http://equalvisibilityeverywhere.org/(accessed Feb. 16, 2018)

5) http://ville.montreal.qc.ca/portal/page?_pageid $=5798,42657625 \&$ dad=portal\&_schema $=$ PORTAL\&id=26453 (accessed Feb. 27, 2018)

6) http://www.parismatch.com/Actu/Politique/Une-rue-aux-noms-de-femmes-dans-chaque-commune-la-proposition-de-deux-centristes-1400807 (accessed Feb. 16, 2018)

7) http://www.toponomasticafemminile.com/ (accessed Feb. 16, 2018)

8) http://deredactie.be/cm/vrtnieuws.english/News/1.3109636 (accessed Feb. 27, 2018)
} 
In Poland the project Wielkopolski Stownik Pisarek aims to commemorate online and in print the women writers of Wielkopolska, ${ }^{9)}$ many of whom have not received much scholarly or media attention so far. A similar initiative in Lublin led to the publication of a volume steeped in the herstory tradition (BIELSKA et al. 2017). The topic is also discussed in the print and electronic media (CHUTNIK 2012; MiLOCH 2017).

\section{Commemorative street names}

"Human memory is spatial. As space is shaped, so is memory. The city, the street, the plaza, any public shared space can be a locus of collective memory. This urban space can have a double function. It can be seen as a receptacle or as an indicator of collective memory. It can identify a group, through physical manifestations such as monuments and symbols, commemorative sites, street names, etc. and it can express the accumulation of memories, through traces left by everyday use." (Hristova 2006, p. 29)

Contemporary hodonyms ${ }^{10)}$ in Polish towns and cities are basically of two types: those motivated by real semantic meaning (e.g. ulica Garbary 'Tannery Street' - named so after the tanners who used to live there; ulica Dworcowa 'Railway Street' - leading to a railway station), and those with arbitrary motivation (e.g. ulica Wersalska 'Versailles Street' - it does not lead to Versailles but commemorates the Treaty of Versailles of 1919). The latter type developed, generally speaking, only in the $19^{\text {th }}$ century. Across this bipartite division goes another one, with five main types (after MYszKa 2012):

1) motivated by street destination: ulica Krakowska 'Cracow Street'

2) motivated by landmarks (historical or still present; invoking the landmark directly or by metonymy): ulica Dworska 'Manor Street'

3) possessive: ulica Dominikańska 'Blackfriars Street'

4) characterising (self-descriptive): ulica Waska 'Narrow Street'

5) commemorative: ulica Mikołaja Kopernika 'Nicolaus Copernicus Street'

However, the commemorative street names of interest here, i.e. those named for individual people (historical or fictitious), ${ }^{11)}$ are for the most part arbitrary, though by way of exception, one can mention street names like ulica św. Magdaleny ('St Magdalene

\footnotetext{
9) A historic region in the west of Poland. The project's website is http://pisarki.wikia.com/wiki/Wielkopolski_S\% C5\%82ownik_Pisarek (accessed Feb. 16, 2018)

${ }^{10)}$ This is the name recommended on the ICOS website. Sometimes they are also called odonyms, and in Polish plateonimy (Greek $\pi \lambda \alpha \tau \varepsilon i \tilde{\alpha}$, Lat. platēa - 'street') or urbanonimy (Lat. urbs 'city', urbanus 'citizen', inhabitant of a city).

${ }^{11)}$ It should be borne in mind that commemorative names, apart from those motivated by personal names, include also those motivated by place names (ulica Warszawska 'Warsaw Street'), by events (ulica Bitwy Warszawskiej $1920 r$. 'Warsaw 1920 Battle Street'), by organisations, military units or formations, etc. (ulica Zwiazku Jaszczurczego 'Lizard Union Street', ulica Pierwszej Brygady 'First Brigade Street') and by other, usually non-specific groups (ulica Ofiar Katynia 'Victims of Katyń [massacre] Street', ulica Bohaterów Monte Cassino 'Monte Cassino Heroes Street').
} 
Street') - perhaps leading to, or situated by, the same-named church, hospital, educational establishment or nunnery. As can be seen in Table 1, in the analysed twelve cities all commemorative names with individual personal (historical or fictitious) namesakes constitute between one fourth (Warsaw) and two fifths (Katowice) of the total hodonymy.

Road names with some commemorative characteristics were already present in Ancient Rome (e.g. Via Flaminia immortalised Gaius Flaminius, who ordered its construction; the genesis of Via Aurelia is analogous). However, it was the $19^{\text {th }}$ century when commemorative naming in its modern sense started, not only in Polish but also in other European towns and cities. One of the first massive-scale ideological street renamings was connected with the French Revolution.

Commemorative names in Poland evoke not only historical figures but also characters from legends, myths or fairy tales, such as Ikar, Guliwer ('Gulliver'), or Szeherezada ('Scheherazade'). Some streets are dedicated to classic literature, both Polish and foreign. The namesakes are both book titles (e.g. Trylogii ${ }^{12}$ ) and individual (or sometimes collective) characters from these books. Examples of streets include Królewny Śnieżki ('Snow White ${ }^{\text {'13) }}$ ) or Kopciuszka ('Cinderella').

Interestingly enough, in some Polish cities there are also streets named simply after given names (Agnieszki, Boranta, Czestawa, Doroty, Kazimierza). While a tiny percentage may have originated as streets named after saints, "secularised" in Communist times ( $s w$. Barbary 'St Barbara' > Barbary), many are new theme bestowals made for no apparent reason, frequently using names not borne by any saint in history (Bożeny, Janusza, Unistawy).

Some linguists perceive the sudden expansion of commemorative street naming as a negative phenomenon:

"Since mid-1 $9^{\text {th }}$ century a category of commemorative names began to develop in Polish cities; they were coined first only from surnames, less frequently from given names of the people to be commemorated, and later also from dates and names of important events in history. The tendency to form such names grew stronger and stronger, until in the second half of the $20^{\text {th }}$ century it disrupted the system because commemorative names dominated, to the detriment of the other types of names, which can be seen mainly in big metropolitan areas, especially in Warsaw as the capital." (HANDKE 2004, p. 92; translation JBW)

\section{Methodology}

The hodonyms analysed in the present article have been extracted from the database TERYT, available from the website of the Central Statistical Office (GUS). Regularly up-

\footnotetext{
12) Trylogia is a series of three historical novels by the Polish writer, Henryk Sienkiewicz (1846-1916), a Nobel-prize winner.

13) All the commemorative names analysed here are in genitive form, which is typical of most Polish commemorative hodonyms. Thus while the street name is (ulica) Królewny Śnieżki, literally 'Snow White's' (street), its namesake is Królewna Śnieżka.
} 
dated, the database provides a complete list of all official hodonyms in current use in Poland: names of streets, avenues, boulevards, passageways, squares, bridges, roundabouts, market squares, city parks and greens, railway and underground stations.

If the same person has been commemorated by more than one object in the same city (such as for instance a street and a park), the commemoration has been counted as double or multiple. A commemoration has been regarded as such irrespective of the type (e.g. street, square, park, etc.), size (big or small) or location (central or peripheral) of the urban feature. Granted, a magnificent avenue in the centre of a city does not have the same commemorative and educational impact as a peripheral lane. However, treating both on a par seemed the only feasible way of tackling the analysed material in terms of numbers. Therefore, and also for brevity, the generic part of the name has not been mentioned.

\section{The scope of the study}

The analysis included twelve Polish cities, in which the number of hodonyms (as of January 2018) was the highest: Warsaw [Warszawa], Cracow [Kraków], Poznań, Łódź, Wrocław, Szczecin, Gdańsk, Bydgoszcz, Lublin, Katowice, Częstochowa and Białystok. It must be emphasised that this list is not identical with the list of the biggest Polish cities in terms of the number of their inhabitants or of their area. For each city, a dictionary devoted to the namesakes or a similar source was consulted (e.g. HANDKE 1998; CIEPŁOWSKi 2002; STANISŁAWSKA-ADAMCZEWSKA and ADAMCZEWSKI 2000; KiTA and NARTONOWICZ-Kot 2012; ANDERs 2006; RzEWICZOK 2013; JURKIEWICZ 1999; JANCEWICZ and SMolKa 2000; Fiedorowicz et al. 2012; Bielska et al. 2017; ArCisZEWSKA 2012). The individual characteristics of these twelve cities - in particular, their size, historical development, or the occupational structure of its inhabitants - differ to a sufficient extent as to ensure representativeness, as briefly outlined below.

Warsaw has been effectively the Polish capital city since 1596, when the royal court was moved here from Cracow (though officially it obtained that status only in 1918). It is nowadays the biggest city in Poland. Its first attested street names appeared in the $15^{\text {th }}$ century, and the first official list of streets was drawn in 1770, when the names already in use were confirmed, and the streets hitherto nameless were named. It was also at the end of the $18^{\text {th }}$ century that theme naming was first introduced in Warsaw, the theme being animal monikers. According to TERYT, there are 5279 hodonyms in Warsaw.

Cracow is one of the oldest cities in Poland - its municipal corporation took place as early as 1257. It was the Polish capital from 1038 to 1596 (with a brief interlude in the years 1295-1296, when Poznań assumed that role) and attested street naming in this city dates back to the $14^{\text {th }}$ century. As regards population, it is today the second biggest Polish city, with the TERYT search yielding 2909 hodonyms.

Poznań ranks fifth among the biggest cities in Poland and it is also one of the oldest. According to recent research, there is high likelihood that it was there that the christening of the first historical Polish ruler took place in 966. Poznań was granted town rights in 1253. At the end of the $18^{\text {th }}$ century it became part of Prussia and remained under Prussian rule - a century later to be replaced with that of unified Germany - until World War I. 
Today it is an important industrial, business and especially educational centre, in terms of the number of university students second only to Warsaw. The number of its hodonyms is 2486 .

Łódź is an industrial city, ranking third in Poland by population. Until the beginning of the $19^{\text {th }}$ century it was a small town with only a handful of streets with official names. It owes its later impressive development to the industrial revolution that transformed the town dramatically in the first half of the 19th century, leading to a massive influx of immigrants in search of employment. Until relatively recently, the base of the city's economy was the textile industry, which earned Łódź the title of "the Polish Manchester". A city map of 1853 shows only five squares and 31 streets, whereas today the number of hodonyms in Łódź amounts to 2387.

With well over six hundred thousand inhabitants, Wrocław (pre-war Breslau), the capital of Lower Silesia, is the biggest city in the so-called Western Borderlands. This location means, among others, that a complete change of its hodonymy (2327 onyms today) took place after World War II. Today it is a university city and a business and cultural centre.

The seaside Szczecin until 1945 was basically a Prussian and later a German city going by the name of Stettin. Consequently, it underwent a massive renaming of its streets after World War II. This fact makes it toponomastically very different from cities like Cracow, which have a long history of naming, mostly within the framework of one linguistic culture. There are 1787 streets and squares in Szczecin.

Another seaside city, Gdańsk (interwar "Free City of Danzig") constitutes - together with Gdynia and Sopot - a conurbation called Trójmiasto ('Tricity'). Gdańsk is the largest city of the ethnic region of Kashubia. It is also famous as the cradle of the Solidarity movement. The number of its hodonyms is similar to that of Szczecin (1732).

Bydgoszcz is a city situated on the waterways, with historical German influence (between 1772 and 1920 part of Prussia, later Germany), which even earned it a nickname of Little Berlin. Today it is an economic and cultural (especially musical) centre, with a population of about 350,000. Bydgoszcz has 1586 hodonyms.

Lublin is situated east of the Vistula. For many centuries it used to be a politically prominent royal town within the Polish-Lithuanian Commonwealth and a centre of commerce. Several Polish Renaissance writers are known to have had links with Lublin. It also played an important role during Reformation (Arianism, Calvinism). Its population today is about 350,000 , and there are 1326 streets and squares.

Katowice is a city in Upper Silesia, marked historically by a dual identity: Polish and German. It owes its prosperity and development - but also its environmental degradation - to coal mining. It is the tenth biggest city in Poland and with 1263 hodonyms, it constitutes part of the so-called Silesian Metropolis, whose population jointly amounts to well over two million people. It has an exceptional history of urban renaming following the year 1922, when it became part of Poland in the aftermath of Silesian Uprisings. Numerous German names of streets were then changed to Polish ones (RzEWICZOK 2013, pp. 8-9). Interestingly, it was probably the only major Polish city whose name was changed in Communist times. The changed name, Stalinogród, lasted for three years (1953-1956).

Częstochowa is a famous pilgrimage centre, developed around a Pauline monastery, founded in 1382. Its erection coincided with the development of the town on the Warta riv- 
er, on the merchant road between two historical regions: Greater Poland (Wielkopolska) and Lesser Poland (Małopolska). The contemporary city has 1263 hodonyms.

Białystok is the largest city of Podlasie, a multiethnic, multicultural, multilingual and multidenominational region in north-eastern Poland. Until the first decades of the $19^{\text {th }}$ century it used to be a small, private town. An impulse to a more dynamic development in the $19^{\text {th }}$ century was the migration of textile entrepreneurs from Łódź and the building of the Saint Petersburg - Warsaw Railway. Today it has nearly 300,000 inhabitants. There are 1124 hodonyms.

\section{Plural namesakes as a methodological problem}

Certain streets (squares, avenues, parks, bridges etc.) commemorate more than one person each. It could be a married couple (e.g. Stanisława $i$ Wandy Miłaszewskich, Marii i Celestyna Rydlewskich, Jarogniewa i Izabeli Drwęskich); a family referred to by their surname in the plural without given names (Cieślewskich, Cichowiczów, Gąsiorowskich, Niegolewskich, Rodziny Hiszpańskich 'the Hiszpański family'), including royal dynasties (Wazów); a family referred to by enumeration (Tadeusza, Marii, Barbary, Włodzimierza Fijewskich); two or more brothers (Braci Zawadzkich 'the Zawadzki brothers'; Jana $i$ Jędrzeja Śniadeckich); two (or sometimes more) people who jointly went down in history (e.g. Żwirki i Wigury); a pair or a larger group of saints (św. Cyryla i Metodego, Serafitek, Sióstr Misjonarek, Urszulanek); two literary characters who appear in a story as a pair (Jasia i Matgosi 'Hansel and Gretel'); a popular music group (Filipinek - an all-female group); finally, an unspecified group, sometimes with uncertain referents (Szyprów 'skippers' - most probably men; Ocalatych 'survivors' - probably both sexes; Czotgistów 'tank soldiers' - usually men).

It is noteworthy that the frequent lack of given names in the urbanonym often makes the commemoration rather enigmatic. This is especially visible in the case of plural namesakes that commemorate a locally eminent family about whom very little is known on the national level. A case in point may be the roundabout rondo Cichowiczów in Poznań. Even the official decision of the local government about the commemoration does not provide information about their given names or about who exactly they were. Only in an earlier document, providing information for the city councillors before the decision was made, one can read the justification: "The Cichowicz family are a Poznań family, in which three people excelled in service for the community, deserving the memory of successive generations of the inhabitants of Poznań" (Uzasadnienie ... 2014) and further their names are mentioned: Ludwik (a lawyer), Helena (his wife, social activist, collector of folklore and founder of a folklore museum), Wiesława (their daughter, singer and curator of the museum). Even if such information were deciphered, there would still remain uncertainty about how to make such data numerically operational, i.e. how to compare a mixed-gender double or multiple namesake with an individual one.

Second, numerous collective namesakes are vague or enigmatic - this regards especially names of professions: Drwali ('the lumberjacks'), Geodetów ('building surveyors'), Ogrodniczek ('the female [!] gardeners'). Finally, it is often uncertain whether the proper 
names in hodonyms refer to men or to women. A case in point might be armies and other military units as namesakes; as such these are rather masculine than feminine, which does not mean than no women serve in them. Some collective namesakes are traditionally considered feminine (Pielęgniarek 'nurses'), other are dubious: Humanistów 'humanists' (may there have been women humanists in Renaissance?), Budowniczych Portu Pótnocnego 'the builders of the North Harbour' (did only men build it?), Elfów 'elves' (males only or both sexes?), and many others. For all these reasons, the present author's decision has been not to include plural namesakes at all. Nevertheless, preliminary research revealed a considerable bias towards male ones.

\section{Other uncertain issues}

In many cases it was uncertain how to treat a street name. For example, Marzanna can be both the name of a Slavic goddess and a female name (it has been decided to treat it as the former, since as a given name it is not very common). Wanda is not only just one of female names, but also the heroine of a well-known Polish legend with a patriotic message, and as such a literary character. In the present article she has been categorised as a legendary character. The Slavic pagan deity names Lada and Kupała as street namesakes posed problems too, since in some sources they are treated as masculine, in others as feminine. Therefore it has been decided to exclude them from the individual commemorative list (both male and female). In Łódź and in Warsaw, a street called Hortensji might be understood as motivated by a female name or by the name of a flower (cf. the same situation in the case of such English names of flowers as hortensia, rose, hyacinth, daisy, lily). In those two particular cases the fact that nearby streets also bear flower-motivated names decided against treating the hodonym as motivated by a female given name. ${ }^{14)}$

Also male names posed classification problems, especially considering an occasional lack of given names of namesakes in street names (e.g. Straszewskiego or Morawiańskiego in Kraków, as well as all the names in Częstochowa that were entered into the database), but also other uncertain issues. Is Lasota, after whom a street in Cracow was named, a rare Slavic given name, or the surname of a locally-known person of merit whose given name was mistakenly omitted? (More research decided in favour of the first option.) JĘDRZEJCZAK 2014 gives several examples of careless urban name-giving with relation to Warsaw. More information on naming mistakes, such as wrong given names, can be found in local media. ${ }^{15}$

Sometimes decisions had to be made about how to classify a namesake - for instance, (Mikołaj) Powała z Taczewa is a historical person, but also a literary figure in the novel

${ }^{14)}$ However, according to HANDKE (1970, p. 116), the name of the street in Warsaw is derived from a female name.

${ }^{15)}$ Cf. e.g. https://radiogdansk.pl/wiadomosci/item/57459-gdanskie-ulice-bledy-w-nazwach-o-ktorych-mozecienie-wiedziec; http://bialystok.wyborcza.pl/bialystok/1,35241,12814307,Radni_pomylili_przydomek_z_imieniem_Ulica_z_bledem.html; http://kielce.naszemiasto.pl/artykul/nasze-ulice-z-wieloma-bledami-az-80nazw-kieleckich-drog, 2634272, art,t,id,tm.html (all accessed Feb. 27, 2018). 
Krzyżacy by H. Sienkiewicz, the author whose literary characters are an especially abundant source of hodonyms in many Polish cities. In this particular case the real existence of a person received priority over his literary presence. Similarly, for consistency, the personages from Ancient Greek mythology (e.g. Mars, Saturn) have been classified as such even in the case of bestowals made within the framework of theme urban naming with astronomy as the theme (as was the case for instance in Białystok).

There are also certain slight inaccuracies in the database - for instance, Jerzy Popiełuszko was beatified after the street was named for him, so the title "blessed" is not part of the street name. Consequently, he has been classified according to the street name, i.e. as a secular historical figure. Also, Oskierki in the database does not contain the given name of its namesake. If it is a literary figure from the novel Potop by Henryk Sienkiewicz, then this is justified, since no given name is revealed in the novel either. However, some Internet sources mention the name Hieronim.

Saints have been counted as such if the name of a particular street included the word świętego or świętej 'saint', błogosławionego or błogosławionej 'beatified', or the respective abbreviations s $s$., $b$. An exception has been made, however, for the late pope John Paul the Second, Mother Theresa and Brother Albert Chmielowski, on the assumption that in Poland those saints are extremely well-known as such.

\section{The findings}

Table 1 presents the results of the analysis, broken down into the data for individual cities. The percentages given in column 7 refer to the ratio of names commemorating female characters in relation to individual commemorative names (ICN), not to all street names (AN) in a city. To give an example, in Warsaw 11.8 percent of individual commemorative names refer to women or female fictitious characters. Since individual commemorative names in Warsaw constitute $25.6 \%$ of all names, in the overall number the names referring to women amount merely to $2.9 \%$. The analogical ratios for the other cities examined are 3.2\% (Cracow), 3.9\% (Poznań), 3.6\% (Łódź), 1.7\% (Wrocław), 3.7\% (Szczecin), 4.3\% (Gdańsk), 1.6\% (Bydgoszcz), 4.2\% (Lublin), 3.4\% (Katowice), 4.8\% (Częstochowa) and $3.9 \%$ (Białystok).

Overall, 25,469 hodonyms in twelve Polish cities have been analysed, among which 7,738 commemorative onyms have been found. Of these, only 848 are names of real or fictitious females, which constitutes 11 percent of the total. However, with the exception of one city (Bydgoszcz), this percentage is raised by the relatively high proportion of names of fictitious female characters, such as heroines of national legends, folk tales, fairy tales, names of Greek mythology goddesses and suchlike, which typically oscillates around 30-45 percent (column 6). With only real-life people considered (column 3), the percentage of female names is markedly lower, between 5.8 percent (Bydgoszcz) and 11.1 percent (Białystok).

Disregarding the names of saints reveals an even greater gender imbalance, because in each of the discussed cities, the percentage of female saints (column 2) was found to be higher than that of female secular personages (column 1). 


\begin{tabular}{|c|c|c|c|c|c|c|c|c|c|c|c|c|c|c|}
\hline \multirow{3}{*}{$\begin{array}{c}\text { City } \\
\text { No. of } A N^{*} \\
\% \text { of ICN* }\end{array}$} & \multicolumn{6}{|c|}{ Historical figures } & \multicolumn{6}{|c|}{ Fictitious characters } & \multicolumn{2}{|c|}{ Total } \\
\hline & \multicolumn{2}{|c|}{ Secular } & \multicolumn{2}{|c|}{ Saints } & \multicolumn{2}{|c|}{ Together } & \multicolumn{2}{|c|}{$\begin{array}{l}\text { Myths / } \\
\text { legends }\end{array}$} & \multicolumn{2}{|c|}{ Other $* *$} & \multicolumn{2}{|c|}{ Together } & & \\
\hline & M & $\mathbf{F}$ & $\mathbf{M}$ & $\mathbf{F}$ & $\mathbf{M}$ & $\mathbf{F}$ & M & $\mathbf{F}$ & $\mathbf{M}$ & $\mathbf{F}$ & $\mathbf{M}$ & $\mathbf{F}$ & M & $\mathbf{F}$ \\
\hline Column number & \multicolumn{2}{|c|}{1} & & \multicolumn{2}{|c|}{3} & \multicolumn{2}{|c|}{4} & \multicolumn{2}{|c|}{5} & \multicolumn{2}{|c|}{6} & \multicolumn{2}{|l|}{7} \\
\hline \multirow{2}{*}{$\begin{array}{c}\text { Warsaw } \\
5,279 \\
\mathbf{2 5 . 6}\end{array}$} & 1,084 & 87 & 16 & 6 & 1,100 & 93 & 28 & 23 & 63 & 43 & 91 & 66 & 1,191 & 159 \\
\hline & \multicolumn{2}{|c|}{$7.4 \%$} & \multicolumn{2}{|c|}{$27.3 \%$} & \multicolumn{2}{|c|}{$7.8 \%$} & \multicolumn{2}{|c|}{$45.1 \%$} & \multicolumn{2}{|c|}{$40.6 \%$} & \multicolumn{2}{|c|}{$42.0 \%$} & \multicolumn{2}{|c|}{$11.8 \%$} \\
\hline \multirow{2}{*}{$\begin{array}{c}\text { Cracow } \\
2,909 \\
\mathbf{3 8 . 2}\end{array}$} & 954 & 57 & 21 & 11 & 975 & 68 & 10 & 9 & 34 & 16 & 44 & 25 & 1,019 & 93 \\
\hline & \multicolumn{2}{|c|}{$5.6 \%$} & 34. & & 6.5 & & 47.4 & & & & 36.2 & & $8.4^{\circ}$ & \\
\hline Poznań & 552 & 64 & 16 & 4 & 568 & 68 & 16 & 5 & 50 & 25 & 66 & 30 & 634 & 98 \\
\hline 29.4 & 10.4 & & 20. & & 10. & & 23.8 & & & & 31.3 & & 13.4 & \\
\hline Lódź & 501 & 46 & 15 & 2 & 516 & 48 & 10 & 6 & 36 & 33 & 46 & 39 & 562 & 87 \\
\hline 27.2 & $8.4^{c}$ & & 11. & & 8.5 & & 37.5 & & & & 45. & & 13.4 & \\
\hline Wroclaw & 549 & 27 & 22 & 10 & 571 & 37 & 2 & 0 & 4 & 3 & 6 & 3 & 577 & 40 \\
\hline $26.5 \%$ & 4.7 & & 31. & & 6.1 & & $0^{\circ}$ & & & & 33. & & $6.5^{\circ}$ & \\
\hline Szczecin & 362 & 32 & 16 & 6 & 378 & 38 & 7 & 4 & 38 & 24 & 45 & 28 & 423 & 66 \\
\hline $27.3 \%$ & $8.1^{\mathrm{c}}$ & & 27. & & 9.1 & & 36. & & & & 38. & & 13.5 & \\
\hline Gdańsk & 421 & 30 & 8 & 4 & 429 & 34 & 36 & 30 & 21 & 11 & 57 & 41 & 486 & 75 \\
\hline $32.4 \%$ & $6.7^{\circ}$ & & 33. & & 7.3 & & 45.5 & & & & 41.8 & & 13.4 & \\
\hline Bydgoszcz & 415 & 25 & 8 & 1 & 423 & 26 & 2 & 0 & 6 & 0 & 8 & 0 & 431 & 26 \\
\hline & 5.7 & & 11. & & 5.8 & & $0^{\circ}$ & & & & $0^{\circ}$ & & $5.7^{\circ}$ & \\
\hline Lublin & 368 & 37 & 8 & 3 & 376 & 40 & 2 & 3 & 29 & 13 & 31 & 16 & 407 & 56 \\
\hline $\begin{array}{l}1,320 \\
34.9 \%\end{array}$ & $9.1^{\circ}$ & & 27. & & 9.6 & & 60. & & & & 34. & & 12.1 & \\
\hline Katowice & 431 & 27 & 12 & 2 & 443 & 29 & 2 & 5 & 22 & 9 & 24 & 14 & 467 & 43 \\
\hline 40.3 & $5.9^{\circ}$ & & 14. & & 6.1 & & 71. & & & & 36.8 & & $8.4^{\circ}$ & \\
\hline Częstochowa & 365 & 30 & 19 & 11 & 384 & 41 & 3 & 0 & 22 & 20 & 25 & 20 & 409 & 61 \\
\hline $\begin{array}{r}1,203 \\
37.2 \%\end{array}$ & $7.6^{6}$ & & 36. & & 9.6 & & $0^{\circ}$ & & & & 44. & & 13.0 & \\
\hline Bialystok & 240 & 27 & 17 & 5 & 257 & 32 & 12 & 3 & 15 & 9 & 27 & 12 & 284 & 44 \\
\hline $29.2 \%$ & 10.1 & & 22 . & & 11. & & 20.0 & & & & 30.8 & & 13.4 & \\
\hline TOTAL & ,242 & 489 & 178 & 65 & 6,420 & 554 & 130 & 88 & 340 & 206 & 470 & 294 & 6,890 & 848 \\
\hline MEAN & $7.3^{\circ}$ & & 26. & & 7.9 & & 30.9 & & 37. & & 38. & & 11.0 & \\
\hline
\end{tabular}

* AN ... all street names, - ICN ... individual commemorative names ** (incl. literary)

Table 1: Visibility of women in commemorative hodonyms in selected Polish cities. The data as of 2 January, 2018 


\section{Discussion}

It can easily be seen that in all cities the number of streets devoted to women is meager vis-à-vis of those devoted to men. It stands to reason that the linguistic image of the world $^{16)}$ that emerges from the street-name analysis reflects real-life hierarchies and relationships in that respect.

Nevertheless, there are differences among particular cities, probably due to a number of diverse factors whose analysis remains well beyond the scope of this article. For instance, it would be easy to account for the relatively masculinised onomastic landscape of Katowice: the traditional Silesian culture posits men as breadwinners working in coal mines, and women as homemakers. It is not as obvious, though, why the situation should be similar in Bydgoszcz. Interestingly, also the relative number of female saints in Katowice is the lowest in comparison with the other cities analysed.

By contrast, the overall number of streets devoted to saints is the highest in Częstochowa, the site of the most famous Catholic shrine in Poland. Relatively many of the commemorated saints are women (36 percent - the highest ratio among the analysed cities), which slightly heightens the otherwise low ratio of secular female namesakes in Częstochowa.

A plausible explanation about the low female ratio in Cracow, invoking the conservative traditions of that royal city, would not be valid with reference to Wrocław, a city of post-war newcomers, where this ratio is even lower. One is forced to admit a multitude of possible factors and dimensions, including conservative vs. liberal leanings of inhabitants, city size, occupational structure (especially the activity of women in the labour market), long vs. short city history, past renamings, etc.

The picture in the twelve cities is somewhat more balanced as regards mythological, legendary, literary and other female characters. Nevertheless, even fictitious characters as street namesakes tend to be men rather than women.

It must be stressed that the large size of the material used in the analysis does not enable speculations about the reasons for the choice of particular street namesakes, since it is not feasible to discuss in one article the individual motivation of over 7,700 hodonyms. The same holds true for the historical perspective. One can only cautiously assume that in the case of Warsaw, Cracow, Poznań, Łódź, Bydgoszcz, Lublin, Katowice, Częstochowa and Białystok most commemorative street names (though certainly not all, especially where the namesakes are saints) are no earlier than 1918, while in the remaining three cities they are no earlier than 1945.

Some numerical differences - especially in the sphere of fictitious characters - could be the work of mere chance. Warsaw, the biggest Polish city, has merely 5,300 hodonyms, ${ }^{17)}$ and the respective number in each other Polish city is significantly lower, which

\footnotetext{
16) A notion known in Polish linguistics as językowy obraz świata (JOS), rooted among others in Humboldtian views on the relationships between language and culture, and especially focusing on the worldview implicitly present in language. One of the attempts to apply JOS to hodonymy is JĘDRZEJKo (2000).

17) By comparison, there are about 60,000 streets or roads in London within a 6 mile radius (http://www.the-london-taxi.com/london_taxi_knowledge).
} 
means that even one sizeable housing estate with theme street naming can visibly distort the overall results.

That the reasons for the gender imbalance in hodonymy are largely cultural is well exemplified by the street name commemoration of the Nobel-winning Curie family. Out of 270 Curie urbanonyms, the majority (261, plus 36 more where only the name Skłodowska is written in full, whereas Curie is non-existent or abbreviated to the initial) honours the Polish-French scientist Maria Curie (née Skłodowska ${ }^{18)}$ ), who won the Nobel prize twice: the first time together with her French husband Pierre, and the second time alone, five years after Pierre's death. Pierre has only one Polish street named after him, the reason probably being his lack of any ties with Poland, other than his marriage. One ambiguous street name (Curie) refers either to Maria or to the whole scholarly family, and the remaining seven commemorations are of Frédéric (in Polish urbanonyms Fryderyk) Joliot-Curie, the husband of one of Maria and Pierre's daughters, Irène. What is emblematic, however, is that while Frédéric received the Nobel prize jointly with Irène, not even one street in Poland is named after her, even though Frédéric's ties with Poland did not go beyond having a Polish-born mother-in-law.

\section{The feminine Pantheon}

The excerption of the female street namesakes from the analysed twelve cities enables the construction of a top-fifty ranking list (in fact, slightly over 50) of historical and fictitious namesakes (Table 2). The names of fictitious characters are in cursive script.

Interestingly, a database search in all of Poland for occurrences of the personages from the list surprisingly yields different results in the top positions. As an absolute record-breaking woman emerges writer Maria Konopnicka, with 774 hodonyms. The second position is occupied by writer Eliza Orzeszkowa (414 hodonyms), and the third one by Jadwiga, king, queen and Catholic saint (309 hodonyms), although in her case it is not certain if some of the streets commemorating simply "St Jadwiga" in fact refer to her, or to another saint by that name, Hedwig of Silesia. Nearly tied for the third place is the double Nobel-prize winner Maria Skłodowska-Curie (297), with further places taken by writers Maria Dąbrowska (168) and Zofia Nałkowska (158), followed by soldier Emilia Plater (144), playwright Gabriela Zapolska (98) and princess Dąbrówka (97).

Clearly, the all-Polish female pantheon is dominated by the literary profession. What might be surprising in this context is the low visibility in public space of poet Wisława Szymborska (72 hodonyms), who is the other Polish female Nobel prize winner (in 1996). It might be noted, in addition, that in all twelve studied cities there was merely one street named for her. This would appear to prove that today's synchronic picture of public space is a reflection of naming processes that were active long ago. Incidentally, all the five

18) In Polish (and therefore also in Polish street names) she appears as Skłodowska-Curie or Curie-Skłodowska, to emphasise her Polish roots and the fact that she spent the first 24 years of life in Poland (under Russian partition at the time). On her hyphenated surname and the order of its components, cf. https://sjp.pwn.pl/ poradnia/haslo/Maria-Sklodowska-Curie;1611.html; http://www.umcs.pl/pl/kolejnosc-nazwisk-150-rocznica-urodzin-marii-curie-sklodows kiej-umcs-lublin,11949.htm\#page-1 (all accessed Feb. 27, 2018). 


\begin{tabular}{|c|c|c|}
\hline $\begin{array}{l}\text { No. of } \\
\text { occurences }\end{array}$ & Name & Area of activity or title to commemoration \\
\hline 14 & Maria Skłodowska-Curie & $\begin{array}{l}\text { Scientist, double Nobel-prize winner (physics, } \\
\text { chemistry) }\end{array}$ \\
\hline 13 & Królowa Jadwiga & King [!] and Queen of Poland, Catholic saint \\
\hline \multirow[t]{2}{*}{12} & Eliza Orzeszkowa & Writer \\
\hline & Emilia Plater & Soldier in national uprising \\
\hline \multirow[t]{3}{*}{11} & Maria Konopnicka & Poet, novelist, author of patriotic anthem \\
\hline & Wanda & Legendary / patriotic \\
\hline & Zofia Nałkowska & Writer \\
\hline \multirow[t]{2}{*}{10} & Gabriela Zapolska & Playwright, novelist \\
\hline & Dąbrówka & $\begin{array}{l}\text { Wife of } 1^{\text {st }} \text { historical Polish ruler, traditionally con- } \\
\text { sidered godmother of Poland }\end{array}$ \\
\hline \multirow[t]{6}{*}{8} & Stefania Sempołowska & Teacher, educator, writer \\
\hline & Helena Modrzejewska & Actress \\
\hline & Danuta Siedzikówna „Inka” & $\begin{array}{l}\text { Medical orderly in WW2, executed } 1946 \text { by Com- } \\
\text { munist authorities }\end{array}$ \\
\hline & Anna Walentynowicz & Activist of free trade unions $1980-1981$ \\
\hline & Grażyna & Literary character in Adam Mickiewicz's poem \\
\hline & Balladyna & Literary character in Juliusz Stowacki's play \\
\hline \multirow[t]{6}{*}{7} & św. Barbara & Christian saint of uncertain historicity \\
\hline & Narcyza Żmichowska & Pioneer feminist, novelist, poet \\
\hline & Maria Dąbrowska & Writer, playwright, translator \\
\hline & Janina Porazińska & Poet, writer for children, translator \\
\hline & Marzanna & Slavic pagan goddess of winter and death \\
\hline & Dziewanna & Slavic pagan goddess \\
\hline \multirow[t]{7}{*}{6} & Pola Gojawiczyńska & Writer, independence movement activist in WW1 \\
\hline & Mieczysława Ćwiklińska & Actress \\
\hline & Kazimiera Iłłakowiczówna & Poet \\
\hline & Królowa Bona & Polish queen \\
\hline & Grażyna Bacewicz & Composer and violinist \\
\hline & Telimena & Literary character in Adam Mickiewicz's epic poem \\
\hline & Świtezianka & Literary character in Adam Mickiewicz's poem \\
\hline \multirow[t]{3}{*}{5} & Zofia Kossak-Szczucka & Novelist \\
\hline & Olga Boznańska & Painter \\
\hline & $\begin{array}{l}\text { Maria Pawlikowska-Jasno- } \\
\text { rzewska }\end{array}$ & Poet \\
\hline
\end{tabular}




\begin{tabular}{|c|c|c|}
\hline $\begin{array}{l}\text { No. of } \\
\text { occurences }\end{array}$ & Name & Area of activity or title to commemoration \\
\hline & Anna Jagiellonka & Polish queen \\
\hline & Aniela Krzywoń & $\begin{array}{l}\text { Soldier, awarded the Gold Star of the Hero of the } \\
\text { Soviet Union }\end{array}$ \\
\hline & św. Anna & Christian saint \\
\hline & Matka Teresa z Kalkuty & Catholic saint \\
\hline & Oleńka Billewiczówna & Literary character \\
\hline & Helena & Female given name \\
\hline & Andromeda & Greek mythological character \\
\hline \multirow[t]{15}{*}{4} & Maria Rodziewiczówna & Novelist \\
\hline & Irena Sendlerowa & $\begin{array}{l}\text { Social work activist, saved thousands of Jewish } \\
\text { children }\end{array}$ \\
\hline & Helena Marusarzówna & Sportswoman (skier), soldier in WW2 \\
\hline & Hanka Ordonówna & Actress and singer \\
\hline & Ewa Szelburg-Zarembina & Novelist, poet, playwright \\
\hline & Emilia Sczaniecka & National activist \\
\hline & Deotyma & Poet and novelist \\
\hline & św. Faustyna & Polish Catholic saint \\
\hline & św. Kinga & Polish Catholic saint \\
\hline & św. Maria Magdalena & Christian saint \\
\hline & Syrena & Legendary character, symbol of Warsaw \\
\hline & Rzepicha & $\begin{array}{l}\text { Legendary character, wife of semi-legendary foun- } \\
\text { der of } 1^{\text {st }} \text { Polish dynasty }\end{array}$ \\
\hline & Hajduczek (Basia) & Literary character in a novel by H. Sienkiewicz \\
\hline & Danusia (Jurandówna) & Literary character in a novel by H. Sienkiewicz \\
\hline & Czerwony Kapturek & Literary character (Little Red Riding Hood) \\
\hline
\end{tabular}

Table 2: Top-fifty ranking list of historical and fictitious female namesakes in twelve Polish cities

above mentioned women writers with high visibility have figured on the school assigned reading lists for decades now.

The synchronic character of the regularly updated database does not allow any inferences about the recent trends. These, however, were the object of the study by JęDRZEJCZAK (2014). His observations are quite different since they were based on a different methodology: he analysed the changes of the names of streets, in Warsaw only, since the end of Communism in Poland (1989). He found that in the years 1989-2014, there appeared 1,111 new street names, whereas 148 names disappeared due to de-Communisation. The ideological changes accounted for 97 (65 percent) of the 148 renamings, with 
the remaining 35 percent due to other factors (such as a change in the course of a street, or making theme naming more consistent). Today 44 (45 percent) of the "ideologically" renamed streets bear the name of a soldier, and 20 (20 percent) of a saint or priest. The proportions among the new bestowals were 45 percent (181 new names) of the military vs. 12 percent (48 new names) of the clergy and 10 percent (42 new names) of politicians. Only 14 percent of individual commemorations involved women, even including literary and fairytale characters. Little wonder, JĘDRZEJCZAK concludes, that the proportion of commemorated women remains low, if the highest chance for a woman to give her name to a street is to have been active in the army or church structures, which are traditionally very masculine; failing that, acting was the third-best choice.

This seems also to confirm the observation made by E. CAFFARELLI: if you are a woman, you had better die in military service on the front if you wish to merit a street named after you. ${ }^{19)}$ While CAFFARELLI's remark was limited to the sphere of journalism, ${ }^{20)}$ it nevertheless pinpointed the problem, i.e. the widespread conviction that sacrificing one's life for one's country or for "the cause" is more important than a peaceful life full of hard work. In fact, one of the opponents of the proposal of gender parity in street naming at the meeting of the city council in Słupsk expressed a similar idea:

"We should respect history, both distant and contemporary. We are speaking here about heroes such as cosmonauts, we are speaking here about places sanctified by blood, such as The Heroes of Westerplatte or Monte Cassino [...] We shall forever argue since we are guided by different principles and priorities. (Protokół ... 2015, p. 57)

\section{Perspectives for the female ratio in commemorative hodonymy}

In outlining the future trends for the visibility of women in Polish hodonymy, three forces can be identified. First, there are the budding bottom-to-top city initiatives, trying to re-claim the city space and symbolically return the city to its "users", which entails empowering ordinary citizens in the decision-making process. In line with this philosophy, there emerge initiatives targeted at reassessing the role of women in history, especially at local level, at remapping the city with the reevaluation of the feminine heritage in mind, and at rewriting the past as herstory. However, there may be top-to-bottom initiatives too. A case in point may be the decision of the city council in Poznań, made in November 2017, that considering the centenary of women's suffrage in Poland in 2018, all the people commemorated in the names of new Poznań streets in 2018 are to be women (KISIEL 2017).

Nevertheless, in contemporary Poland there is also a growing tendency - reflected in numerous top-to-bottom initiatives on the national level, and intensified since the

\footnotetext{
19) "Se ci spostiamo nel settore giornalistico, notiamo che, se si è donna, è necessario morire in servizio sul fronte di guerra per meritare un odonimo." (CAFFARELli 2012, p. 33)

${ }^{20)}$ He was in fact alluding to Ilaria Alpi, an Italian journalist killed in Mogadishu in 1994 (I am grateful for this explanation to Claudia ANTOLINI).
} 
parliamentary victory of the right-wing party "Law and Justice" in the autumn of 2015 - to reevaluate the past. The national pantheon undergoes radical changes and a new politics of memory is forged, with particular emphasis on representatives of the military, the clergy and the members of the anti-communist Polish resistance movements in the years that directly followed the end of World War II. Even though this trend accounts for the marked increase in the number of commemorations of the hitherto relatively little-known Danuta Siedzikówna "Inka" (currently 35 hodonyms), those heroes were mostly men.

The third trend reflects the marketing needs of developers - but perhaps also the secret yearnings of many ordinary people, tired of name-changing propelled by political shifts. Nice, neutral-sounding street names, such as Zielone Zacisze ('Green retreat'), gain in popularity (KALTENBERG-KWIATKOWSKA 2011, pp. 145-146). As JĘDRZEJCZAK (2014) observes, "the concentration of Stork Nooks, Sunny Mornings, Quiet Backstreets, Morning Dews, Forest Brooks and Birch Groves can be nauseating to the healthiest of men". Obviously, this trend shuns commemorative hodonymy, regardless of the personages commemorated; therefore, if it were followed, the female ratio in commemorative street naming would not be likely to increase.

\section{References}

ANDERS P. (2006): Patroni wielkopolskich ulic [People after whom the streets of Poznań are named]. Poznań, Wydawnictwo Wojewódzkiej Biblioteki Publicznej i Centrum Animacji Kultury.

Arciszewska A. (2012): Nazewnictwo miejskie dzielnic, placów i ulic Katowic [The hodonymy of Katowice: districts, squares, streets]. Językoznawstwo: współczesne badania, problemy i analizy językoznawcze, 6, pp. 7-17.

Bielska L., Juros J., Szewciów M. (2017): Lubelskie szlaki herstoryczne [Herstorical trails of Lublin]. Lublin, Fundacja HerStory.

Bosworth M. (2012): Are Our Street Names Sexist? BBC World Service. - www.bbc.com/news/ magazine-17203823 (accessed Feb. 16, 2018).

CAFFARElli E. (2012): Odonimi: dalla funzione descrittiva a quella pedagogico-celebrativa e simbolica. Con tre proposte per le dedicazioni al femminile [Hodonyms: from the descriptive function to the pedagogical-commemmorative and symbolic one. Three proposals for feminine street naming]. In: Ercolini M. P. (ed.): Sulle vie della parità: Atti del I Convegno di Toponomastica femminile, Roma 6-7 ottobre 2012 [On the paths of equality: Proceedings of the First Convention on Female Toponymy, Rome, October 6-7, 2012]. Roma, UniversItalia, pp. 27-34.

Chutnik S. (2012): Czyje ulice? Nasze ulice [Whose streets? Our streets]. Warszawa, Gazeta Wyborcza, Wysokie Obcasy, issue Feb. 24, 2012

Cieplowski S. (2002): Słownik patronów ulic Warszawy [Dictionary of people after whom the streets of Warsaw are named]. Warszawa, Wydawnictwo DiG.

Fiedorowicz T., KietLiŃski M., MACIEJCZuK J. (2012): Białostockie ulice i ich patroni [The streets of Białystok and the people after whom they are named]. Białystok, Prymat.

HANDKE K. (1970): Semantyczne i strukturalne typy nazw ulic Warszawy [Semantic and structural types of the names of streets of Warsaw]. Wrocław - Warszawa - Kraków, Zakład Narodowy im. Ossolińskich. 
HANDKe K. (1998): Słownik nazewnictwa Warszawy [Dictionary of Warsaw hodonymy]. Warszawa, Slawistyczny Ośrodek Wydawniczy.

HANDKe K. (2004): Nazewnictwo miejskie - składnik edukacji społecznej [Hodonymy - part of social education]. In: MrózeK R. (ed.): Nazwy własne w języku, kulturze i komunikacji społecznej [Proper names in language, culture and social communication]. Katowice, Wydawnictwo Uniwersytetu Śląskiego, pp. 89-97.

Hristova Z. (2006): The Collective Memory of Space: The Architecture of Remembering and Forgetting. Toronto, Ryerson University.

Jancewicz B., SmoŁka L. (eds.) (2000): Nazwy ulic Wrocławia [Names of the streets of Wrocław]. Wrocław, Towarzystwo Miłośników Wrocławia.

J̨̨DRZEJCZAK A. (2014): Ksiądz z generałem w porannej rosie - o nazewnictwie warszawskich ulic [A priest with a general in the morning dew - about the naming of Warsaw streets]. - http:// www. panskaskorka.com/o-nazewnictwie-warszawskich-ulic-2/(accessed Feb. 22, 2018)

JęDRZejko E. (2000): Durch die Straßen der Städte wandernd ...: kontrastive Onomastik und sprachliche Weltbilder (am Beispiel polnischer und deutscher Straßennamen) [Walking through the streets of the city: Contrastive onomastics and the linguistic image of the world (as exemplified by Polish and German street names)]. In: Feine A., ŻydeK-BednarczuK U. (eds.): Beiträge zur Nomination im Deutschen und im Polnischen [Contributions to the nomination in German and in Polish]. Katowice, Wydawnictwo Uniwersytetu Śląskiego, pp. 48-70.

JuRkiewicz J. L. (1999): Patroni szczecińskich ulic [People after whom the streets of Szczecin are named]. Stargard, Oficyna Wydawnicza INA.

KALTENBERG-KWIATKOWSKA E. (2011): O oznaczaniu i naznaczaniu przestrzeni miasta [On marking and naming the city space]. In: Przegląd Socjologiczny, 60, 2/3, pp. 135-165.

Kensche C. (2013): Farce um Frauenquote für Straßennamen in Berlin [Farcical gender quotas in naming streets in Berlin]. In: Welt, Panorama, issue April 24, 2013. - https://www. welt.de/vermischtes/kurioses/article115541901/Farce-um-Frauenquote-fuer-Strassennamen-in-Berlin.html (accessed Feb. 22, 2018)

Kisıel B. (2017): Poznań: W 2018 roku więcej kobiet zostanie patronkami ulic [Poznań: more women after whom to name streets in 2018]. In: Poznań, Głos Wielkopolski, 21 listopada 2017. - http://www.gloswielkopolski.pl/wiadomosci/poznan/a/poznan-w-2018-roku-wiecej-kobiet-zostanie-patronkami-ulic, 12694032/ (accessed Feb. 22, 2018).

Kita J., Nartonowicz-Kot M. (2012): Nazewnictwo ulic Łodzi. Rys historyczny [Hodonymy of Łódź. A historical outline]. Łódź, Księży Młyn.

MiLoch M. (2017): Kobiety na patronki ulic [Streets should be named after women]. - https://kobieta.wp.pl/kobiety-na-patronki-ulic-6098226018456193a (accessed Feb. 22, 2018).

MyszKa A. (2012): Ewolucja motywacji współczesnych nazw ulic województwa podkarpackiego [Evolution of the motivation of contemporary street names in Podkarpackie Voivodeship]. In: OLošTiaK M (ed.): Jednotlívé a všeobecné v onomastike [The individual and the general in onomastics]. Prešov, Filozofická fakulta Prešovskej univerzity v Prešove, pp. 262-273.

Poon L. (2015): Mapping the Sexism of City Street Names. - https://www.citylab.com/equity/ 2015/11/mapping-the-sexism-of-city-street-names/414094/(accessed Feb. 22, 2018).

Protokół nr XV/15 sesji Rady Miejskiej w Słupsku z dnia 30 września 2015 r. [The minutes of the XV/15th meeting of the City Council in Słupsk on Sept. 30,2015]. - http://bip.um.slupsk.pl/ rada_miejska/protokoly_z_posiedzen_rady_miejskiej/23749.html (accessed Oct. 30, 2015).

Rzewiczok U. (2013): Patronowie katowickich ulic i placów [People after whom the streets and squares of Katowice are named]. Katowice, Muzeum Historii Katowic.

StanisŁawska-Adamczewska T., Adamczewski J. (2000): Kraków, ulica imienia ... [Names of streets in Cracow]. Kraków, Oficyna Wydawnicza "BiK". 
Tojo M. (2015): Santas y vírgenes representan a las mujeres en el callejero español [Saints and virgins represent women in Spanish streets]. - http://www.eldiario.es/sociedad/Santas-virgenes-representan-callejero-espanol_0_353814783.html (accessed Feb. 22, 2018).

Uzasadnienie do projektu uchwały Rady Miasta Poznania [nr LXVI/1050/VI/2014 - author's note] w sprawie nadania nazw rondom [Justification for the draft resolution of the Poznan City Council concerning naming roundabouts]. Feb. 24, 2014. - http://tiny.pl/gn56c (accessed Feb. 22, 2018). 